\title{
Correction to: Artificial recharge of a shallow hard rock aquifer as a climate change mitigation method: model solution from the Czech Republic
}

\author{
David Rozman $^{1,2} \mathbb{D} \cdot$ Zbyněk Hrkal $^{1,2} \cdot$ Miroslav Tesař $^{3}$
}

Published online: 11 December 2018

(c) The Author(s) 2018

\section{Correction to: Modeling Earth Systems and Environment https://doi.org/10.1007/s40808-018-0552-8}

The article Artificial recharge of a shallow hard rock aquifer as a climate change mitigation method: model solution from the Czech Republic, written by David Rozman, Zbyněk Hrkal, Miroslav Tesař was originally published electronically on the publisher's internet portal (currently Springer Link) on February 23, 2018 without open access.

With the author(s)' decision to opt for Open Choice the copyright of the article changed on (December 2018/14th November 2018) to (C) The Author(s) (2018) and the article is forthwith distributed under the terms of the Creative Commons Attribution 4.0 International License (http:// creativecommons.org/licenses/by/4.0/), which permits use, duplication, adaptation, distribution and reproduction in any medium or format, as long as you give appropriate credit to the original author(s) and the source, provide a link to the Creative Commons license and indicate if changes were made.

The original article was corrected.

Open Access This article is distributed under the terms of the Creative Commons Attribution 4.0 International License (http://creativeco mmons.org/licenses/by/4.0/), which permits unrestricted use, distribution, and reproduction in any medium, provided you give appropriate credit to the original author(s) and the source, provide a link to the Creative Commons license, and indicate if changes were made.

Publisher's Note Springer Nature remains neutral with regard to jurisdictional claims in published maps and institutional affiliations.

The original article can be found online at https://doi.org/10.1007/ s40808-018-0552-8.

David Rozman

david.rozman@vuv.cz

1 Faculty of Science, Charles University, Albertov 6, Prague, Czech Republic

2 T.G. Masaryk Water Research Institute, Podbabská 30, Prague, Czech Republic

3 Academy of Sciences, Hydrodynamic Institute, Podbabská 13, Prague, Czech Republic 